\title{
CONVENTIONAL AND MOLECULAR DETECTION OF INTRAMAMMARY STAPHYLOCOCCUS AUREUS INFECTION IN CLINICAL AND SUBCLINICAL MASTITIS OF BUFFALOES WITH A FIELD THERAPEUTIC TRIAL
}

\author{
A.M.A. ZAITOUN ${ }^{1}$; A.S. ABD-EL-WAHED ${ }^{2}$; ALSAGHER O. ALI ${ }^{3}$ and RADWA HARTH ${ }^{4}$ \\ ${ }^{1}$ Infectious Diseases, Dept. Animal Med., Faculty Assiut Univ. \\ ${ }^{2}$ Laboratory and Clinical Diagnosis, Faulty of Vet. Med. South Valley Univ. \\ ${ }^{3}$ Infectious Diseases, Dept. Animal Med., Faculty Assiut Univ. \\ ${ }^{4}$ Veterinary Directorate, Sohag Governorate \\ This article is an abstracted from extracted from M.V. Thesis edited by the Fourth author under supervision of the \\ first-three author presented to Infectious Diseases, Dept. Animal Med., Faculty of Vet. Med., South Valley Univ.
}

Received: 30 December 2018; Accepted: 23 January 2019

\begin{abstract}
Prevalence of Staphylococcus aureus mastitis in buffaloes was fundamentally aimed in the current work using culturing procedures and PCR Assay. Field therapeutic trial with follow-up for 10 consecutive weeks post therapy was carried out with monitoring of shedding pattern of Staphylococcus aureus. Three hundred and eighty buffaloes of different lactation seasons were examined in Sohag Governorate. Prevalence of clinically and subclinically infected buffaloes was $10.52 \%$ and $26.84 \%$, respectively. Epizootiologically, prevalence of clinically and subclinically infected animals with mastitis in the $2^{\text {nd }}, 3^{\text {rd }}$, and $4^{\text {th }}$ lactation seasons was $12.00 \%$ and $32.00 \%$; $20.83 \%$ and $41.67 \%$; and $22.73 \%$ and $36.36 \%$, respectively. Thereafter the trend of mastitis was significantly declined by increasing the numbers of lactation season. Over the $9^{\text {th }}$ lactation season, there were no signs of mastitis. Bacteriologically, Staphylococcus aureus was the predominant pathogen followed by Streptococcus agalactiae and Escherichia coli. Staphylococcus aureus were sensitive to amoxicillin, enrofloxacin and ciprofloxacin but $50 \%$ of the tested strains were resistant to penicillin and oxytetracycline. A Field therapeutic trial with synulox (Amoxicillin plus Clavulanic acid) with anti-inflammatory and supportive drugs was carried out in 10 diseased buffaloes ( 3 clinical and 7 subclinical). Three clinical and three subclinical forms were culled due to failure of therapy. Four cases of subclinical mastitis were apparently successfully treated. Shedding pattern of Staphylococcus aureus during the therapeutic period was weekly monitored and revealed that shedding was intermittent. In conclusion, Staphylococcus aureus is an outstanding notoriousness mastitogen and its early detection considers a crucial goal in control. PCR is a valuable test for detection of mastitogens than culture techniques but it is still precious practically.
\end{abstract}

Key words: Staph aureus mastitis culture, PCR, Therapy, Epizootiology, shedding pattern

\section{INTRODUCTION}

Mastitis is continuously implicated as a major problem of milk-producing animals inducing considerable level of economic losses. In Egypt, Buffaloes' milk is more preferable than cows' milk. Mastitis is caused by various mastitogens. However, Staphylococcus aureus is a prominent mastitiogen than others (Javaid et al., 2009). Subclinical form mastitis appears to be more seriousness than clinical form due to the hidden nature of the clinical abnormalities and due to the lack of the periodical testing of the milk-producing animals on farms. Unfortunately, the majority of the buffaloes' owners have no adequate awareness concerning

Corresponding author: A.M.A. ZAITOUN

E-mail address: amazaitoun@aun.edu.eg.

Present address: Infectious Diseases, Dept. Animal Med., Faculty Assiut Univ. regular testing of udders and their secretions of dairy animals in association with the accepted level of sanitary measures. (Miller et al., 1993; Javaid et al., 2009 and Sharif and Muhammad 2009). Moreover, Buffalo is also recognized as the world second most important milk producing species (McDowell et al., 1995; Bhatti et al., 2009).

Despite susceptibility to mastitis is low in buffaloes when compared to cattle (Saleh, 2005), the poor management conditions practiced by small buffalo holders in rural areas may anticipate in increased percentage of subclinical mastitis. Staphylococcus aureus causes many serious diseases in humans and animals, and it is the most common etiologic agent of contagious bovine mastitis, with relevant losses in the dairy industry. Mastitis caused by $S$. aureus bacteria is extremely difficult to control by treatment alone. The organism usually does not respond to antibiotic treatment, and infected cows culled from 
the herd. S. aureus bacteria produce toxins that destroy cell membranes and can directly damage milk producing tissue. It produces an enzyme that inactivates most penicillin-based treatments, resulting in ineffective antibiotics (Jones et al., 1998). Formation of micro abscesses by $S$. aureus helps intramammary localization and protects $S$. aureus from polymorph nuclear cells (PMN) activity and antimicrobial therapy (Gudding et al., 1984).

El-Balkemy et al. (1997) concluded the CMT is still the superior screening diagnostic aid for subclinical mastitis, while bacteriological examination is still the most suitable accurate and reliable method to confirm the causative organisms.

On the other hand, subclinically infected cows are intermittent shedders of organisms and may cycle through low and high shedding patterns during lactation. Milk culture may yield no bacteria from truly subclinically infected glands due to the presence of very low numbers of pathogens when samples are collected (Cai et al., 2003). Negative cultures may also be due to bacteria inhibited by residual therapeutic antimicrobials or leukocytes. Environmental contaminants and intracisternal microorganisms can also represent a major problem in the interpretation of culture results. Moreover, microbiological culture of milk is time consuming. Species identification by standard biochemical methods requires more than $48 \mathrm{~h}$ to complete (Phuektes et al., 2001).

Due to the limitations of conventional culture, simplex and multiplex PCR protocols have been developed for identification of mastitis pathogens (Daly et al., 2002; Meiri-Bendek et al., 2002; Anand Kumar, 2009; Kozytska et al., 2010). These PCR methods offer the option of identification of bacteria within hours. PCR can also improve the level of detection because of its ability to detect low amount of organisms' nucleic acid. Mastitis pathogens could probably be detected in carrier animals or at earlier stages of infection in clinical cases. PCR also has the potential to be extremely specific and to discriminate between closely related microorganisms, such as $S$. parauberis and S. uberis (Jayarao et al., 1991). Therefore, prevalence of $S$. aureus mastitis in buffaloes was aimed in the current work. Field therapeutic trial with follow-up for 10 consecutive weeks was also carried out with monitoring of shedding pattern of $S$. aureus.

\section{MATERIALS AND METHODS}

\section{Animals:}

A total of 380 randomly selected buffaloes were included in the present study located in different localities of Sohag Governorate in Upper Egypt. Examined animals were primiparous and/ or multiparous and they were different in lactation seasons which ranged from the $1^{\text {st }}$ to $10^{\text {th }}$ seasons. These animals were reared on an open yard.

\section{Samples:}

Clinically infected buffaloes were aseptically sampled in screw-capped bottles and stored in ice box. If the mastitic case was infused with antimastitic drug, the milk samples were retaken on week later post medication. Also subclinically positive cases were aseptically sampled. Collection of milk samples was carried out according to outlines illustrated by Andrews et al. (1992). The collected samples were transported to the laboratory of infectious diseases, Department of Animal Medicine, Faculty of Veterinary Medicine, Sohag University, for bacteriological examination as rapid as possible.

\section{Clinical examination:}

Buffaloes examined clinically (visual inspection and physical examination) for detection of signs of mastitis which appear grossly on udder and/or milk with and / or without systemic reactions as described by (Jackson and Cockroft, 2002). Data of all clinically examined buffaloes were recorded and enrolled, according to the design illustrated by Kelly (1984).

\section{California Mastitis Test:}

CMT and its scores were carried out as described by the manufacturer Delval mastitis test, Poland, batch number: 3505503 . The animals give positive result with CMT was sampled.

\section{Laboratory diagnosis of mastitis:}

Each milk sample was subjected to preparation of milk smear followed by culturing procedure:

\section{Milk smear:}

Collected milk sample incubated for overnight at first then centrifuged. Milk smears were prepared and stained by loeffler s methylene blue stain and by Gram s stain according to the methods described by Watts (1990).

\section{Culturing procedure and Biochemical tests:}

Bacterial methods, using blood, McConkey and mannitol salt agars and the biochemical characterizations were previously described (Watts, 1990; Koneman et al., 1992; and Quinn et al., 1994).

\section{Polymerase Chain Reaction (PCR):}

PCR technique was done for recognition of the Staphylococcus aureus in mastitis milk samples by detection of nuc gene through the followings: 


\section{DNA extraction directly from milk:}

Two methods were carried out for extraction of DNA from the tested milk samples; Spin Column Extraction and Phenol-Chloroform Extraction.

\section{Phenol-Chloroform Extraction of DNA from Milk Samples:}

DNA from milk samples was extracted by the method described previously by Phuektes et al. (2001) with some modification reported by Sindhu et al. (2010).

\section{Spin Column Extraction of DNA from Milk Samples:}

One hundred microliters of each milk sample was mixed vigorously with $350 \mu$ l of RLT buffer (Qiagen, Germany) containing $1 \% \quad 2$ mercaptoethanol, then $300 \mu \mathrm{l}$ of $100 \%$ ethanol was added, followed by $15 \mu \mathrm{l}$ of Qiaex II matrix (Qiagen). The suspension was loaded onto a spin column (Axygen, Hayward, CA). Columns were centrifuged for $30 \mathrm{~s}$ at $9000 \times \mathrm{g}$, and the flow through was discarded. The columns were washed once with $600 \mu \mathrm{l}$ of RLT buffer and then washed twice with $500 \mu$ l of RPE buffer (Qiagen). For each wash, the columns were centrifuged at $9000 \times \mathrm{g}$ for 30 s. After the final wash, the columns were centrifuged for an additional $1.5 \mathrm{~min}$ at $16,000 \times \mathrm{g}$ to remove any excess ethanol. Thirty microliters of RNase-free water was placed directly on the matrix. The DNA was eluted from the matrix by centrifugation at $9000 \times \mathrm{g}$ for $1 \mathrm{~min}$ and $5 \mu \mathrm{l}$ of the extract was subjected to PCR.

\section{Extraction of DNA from Broth Cultures of Milk Samples:}

A well biochemically identified strain of Staphylococcus aureus was inoculated into $10 \mathrm{ml}$ of Trypticase soya broth and incubated at $37^{\circ} \mathrm{C}$ for 12 hours prior to extraction. Three hundred microliters of broth culture was used for DNA extraction using the phenol-chloroform method and $100 \mu$ was used for extraction using the spin column method as described above. These samples were utilized as a control positive in PCR procedure.

\section{DNA amplification reaction:}

Amplification was carried out as previously described by (Hatakka et al., 2000).

\section{Antimicrobials Sensitivity Test (AST):}

AST was done by disc diffusion technique using Mueller-Hinton agar medium as previously described by Bauer et al. (1966) and National Committee for Clinical Laboratory Standards (1984). The zones of inhibition were mathematically measured and compared with applied data illustrated by Ranjan et al. (2010), CLSI, (2008) \& (2014).

\section{Field Therapeutic Trial with follow-up:}

Based on the results of sensitivity test, Synulox Lactating Cow intramammary infusion (SLC) (amoxicillin, clavulanic acid and prednisolone) was the commercial antimastitic drug of choice to do the Field Therapeutic Trial. The product is presented in disposable intramammary syringes containing 200 $\mathrm{mg}$ amoxicillin as amoxicillin trihydrate, $50 \mathrm{mg}$ clavulanic acid as potassium clavulanate and $10 \mathrm{mg}$ prednisolone in $3 \mathrm{~g}$ suspension. Intramammary infusion was done twice daily for 3 consecutive days (6 udder infusion per infected quarter). In Paralleling with the udder infusion, Synulox RTU Injection that contains (amoxicillin $140 \mathrm{mg}$ and clavulanic acid 35 $\mathrm{mg}$ ) as a systemic application was also applied in a dose of $10 \mathrm{mg}$ per $\mathrm{Kg}$ body weight per day for 3 consecutive days. Ten $\mathrm{cm}$ of Flunixin injection (Flunixin meglumin $50 \mathrm{mg} / \mathrm{ml}$, Noorbrok) were intramuscularly injected. Fat sol. Vitamins were done in form of $\mathrm{AD}_{3} \mathrm{E}$ (Liquivit, ADWAIA Co.), daily supplementation and Vitamin $\mathrm{C}$ (Adevit $C$, $A D W A I A \mathrm{Co}$ ) was injected daily in case of pyrexic cases as prescribed by the manufactures. Follow-up of the treaded cases was weekly monitored by culturing or PCR testing of their milk for 10 consecutive weeks (Table 4).

\section{Statistical analyses:}

The collected data of the examined dairy buffaloes was pooled. The prevalence (percentage of the affected cases) of the subclinical and the clinical mastitis of dairy buffaloes was calculated by conventional methods. During the period of investigation, a randomly selected 380 buffaloes in different lactation seasons (different ages) were subsequently examined. The linear relationship between prevalence ( $\%$ affected) of clinical and subclinical mastitis of the examined buffaloes at different lactation seasons was statistically studied using simple linear regression according to the methods illustrated by Chatfield (1970). To increase the fitness, lactation seasons of the examined buffaloes were divided to two sets (stages). The first set was from the first to the fourth lactation season, and the second stage was from the fifth to the tenth lactation seasons. Subsequently the simple regression line equation was divided into two sets (1 and 2) according to the lactation numbers of the examined dairy buffaloes on farm to increase the

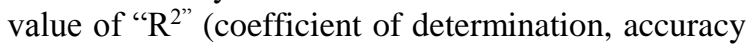
percentage). Regression equations are usually meaningful if the correlation " $r$ " between the variables can shown to be significant. Pearson's $r$ was used to describe the degree of linear correlation between two variables $\mathrm{X}$ (percentage of infection 
with mastitis) and Y (lactation season). Calculation of Pearson's "r" was achieved by Meddis (1975).

\section{RESULTS}

\section{Clinical Findings:}

Clinical examinations of the examined buffaloes ( $\mathrm{n}$ $=380)$ indicated $40(10.53 \%)$ cases showed signs of clinical mastitis. Acute form of mastitis was found in $16(40.00 \%)$ cases. Of these acute cases $(n=16)$ $40.00 \%$, there were $11(68.75 \%)$ buffaloes showed systemic reactions with the cardinal signs of inflammation of the infected quarters (swollen, hotness, severe pain and pinkish discoloration). The diseased buffaloes with acute form of mastitis were in abduction of the hind-limbs. Five $(32.25 \%)$ cases of acute mastitis form $(n=16)$ showed no systemic signs with the cardinal signs of inflammation of affected quarters.

Subacute / chronic mastitis were observed in 24 $(60.00 \%)$ cases of the diseased buffaloes with signs of clinical mastitis (swelling of the mammary quarters without signs of pain or hotness). Of these subacute and/or chronic cases $(n=24), 7(29.17 \%)$ cases showed hard texture of their affected quarters with indurations followed by regression of their sizes and fibrosis.

The affected quarters of the remained cases $(\mathrm{n}=17$, $70.83 \%$ ) were found in atrophied condition and the symmetrical shape of the udder quarters was changed. The udder appeared as free sac-like shape. Udder and teat wounds or abrasions were noticed in the most cases of clinical mastitis of pain on the animals were monitored.

Mammary secretions of the diseased buffaloes with clinical mastitis lost its characteristic odor and appearance. The glossily milky color of buffaloes, milk was disappeared and by centrifugation the collected milk samples precipitate an aggregation of erythrocytes. Fifteen cases of the secreted was brownish yellow in color, watery in consistency and mostly with bloody clots. Ten diseased buffaloes yielded watery yellowish-colored milk secretions with white clotted milk-flakes.

There were five cases of the diseased buffaloes; their mammary secretions were dark yellow discoloration and thick purulent discharge with putrefied offensive odor. Another seven cases their mammary secretions were light yellow discoloration and its consistency was serous contains flakes. The mammary secretions of the remained cases $(n=3)$ were yellowish in color with unpleasant odor.

Confined to quarter affected; it was found that $11 / 21$ $(52.47 \%)$ mastitis buffaloes had one quarter infection followed by $5 / 21 \quad(23.8 \%)$ buffaloes infected in two quarters and 3/21 (14.38\%) buffaloes infected in three quarters and 2/21 (9.52\%) buffaloes infected in four quarters. Prevalence of clinical and subclinical mastitis of the examined cases $(n=380$ buffalo) at different lactation seasons were tabulated in (Table1).

\section{Bacteriological examinations:}

The bacteriological examinations of the collected milk samples $(n=142)$ from the diseased buffaloes with clinical $(n=40)$ and subclinical $(n=102)$ mastitis of the investigated farm was tabulated (Table 2 and Fig. 1). Staphylococcus aureus was the most frequently isolated pathogens followed by Streptococcus agalactiae, Escherichia coli and Coagulase negative staphylococci. On the other side, the bacteriological results revealed that Trueperella pyogens was less isolated pathogen $(2.50 \%)$.

\section{Epizootiological view:}

In regarding to the age susceptibilities of the examined dairy buffaloes and the infection rate with subclinical and/or clinical mastitis, the obtained results indicated that the trend of the infection rate with subclinical mastitis was gradually ascending (from the $1^{\text {st }}$ lactation to the $4^{\text {th }}$ lactation season, $r=$ $97 \%$ ) by increasing the number of lactations (age) of the examined case (Fig.1 and 2). Thereafter the trend of the infection rate was gradually descending (from the $5^{\text {st }}$ lactation to the $9^{\text {th }}$ lactation season, $r=99 \%$ ). The current work also indicated that aged buffaloes more than 9 years were found negative results of mastitis.

On the other side, the obtained results revealed that the trend of the rate of infection with clinical mastitis was also gradually increased (from the $1^{\text {st }}$ lactation to the $4^{\text {th }}$ lactation season, $r=96 \%$ ) by increasing the number of lactations of the examined Fig. 4 and 5). Thereafter the trend of the infection rate was slowly descending (from the $5^{\text {st }}$ lactation to the $9^{\text {th }}$ lactation season, $r=99 \%$, Fig. 4 and 6). Buffaloes more than 9 years were also found to mastitis-free.

\section{Antimicrobials Sensitivity Test:}

Results of the sensitivity test of the predominant mastitis pathogens isolated from clinical and/or subclinical mastitis cases were illustrated in Table 3 .

\section{Field therapeutic trial:}

Therapeutic results were enrolled in Table 4. There were three cases of clinical mastitis form and three cases of subclinical mastitis form were culled out due to failure of therapy trial. Four of subclinical form of mastitis was successfully treated.

\section{PCR:}

Negative bacteriologically examined samples were reexamined molecularly by PCR. PCR reaction revealed eight positive amplicons of $\boldsymbol{N U C}$ gene and there length $270 \mathrm{bp}$ in the presence of negative and positive controls which is characteristic for $S$. aureus (Fig. 2). 
Table1: Prevalence of clinical (CM) and subclinical mastitis (SCM) of dairy buffaloes (private animals) at different lactation seasons.

\begin{tabular}{|c|c|c|c|c|c|}
\hline \multirow{2}{*}{$\begin{array}{l}\text { Lactation } \\
\text { season }\end{array}$} & \multirow{2}{*}{$\begin{array}{l}\text { Number of } \\
\text { examined cases }\end{array}$} & \multicolumn{2}{|c|}{ Cases with CM } & \multicolumn{2}{|c|}{ Cases with SCM } \\
\hline & & No. & $\%$ & No. & $\%$ \\
\hline 1 & 54 & 2 & 3.70 & 10 & 18.52 \\
\hline 2 & 50 & 5 & 10 & 16 & 32.00 \\
\hline 3 & 48 & 10 & 20.83 & 20 & $\overline{41.66}$ \\
\hline 4 & 44 & 11 & 25.00 & 16 & 36.36 \\
\hline 5 & 40 & 7 & 17.50 & 14 & 35.00 \\
\hline 6 & 42 & 4 & 9.52 & 12 & 28.57 \\
\hline 7 & 34 & 1 & 2.94 & 8 & 23.52 \\
\hline 8 & 27 & $\overline{\mathbf{0}}$ & $\mathbf{0}$ & 4 & 14.81 \\
\hline 9 & 25 & $\mathbf{0}$ & 0 & 2 & 8 \\
\hline$>9$ & 16 & $\mathbf{0}$ & $\mathbf{0}$ & $\mathbf{0}$ & $\mathbf{0}$ \\
\hline Total & 380 & 40 & 10.52 & 102 & 26.84 \\
\hline
\end{tabular}

Table 2: Bacteriological examinations of the tested mammary secretion-samples of the diseased buffaloes $(n=$ $142)$ with clinical $(n=40)$ and subclinical $(n=102)$ mastitis.

\begin{tabular}{|c|c|c|c|c|c|}
\hline \multirow[b]{2}{*}{$\begin{array}{l}\text { The major isolated } \\
\text { mastitis pathogen(s) }\end{array}$} & \multicolumn{2}{|c|}{ Clinical mastitis } & \multicolumn{2}{|c|}{ Subclinical mastitis* } & \multirow[b]{2}{*}{$\begin{array}{c}\% \text { to all } \\
\text { mastitis } \\
\text { cases }\end{array}$} \\
\hline & $\begin{array}{c}\text { Number of } \\
\text { cases }\end{array}$ & $\begin{array}{c}\% \text { to all } \\
\text { clinically } \\
\text { mastitis cases }\end{array}$ & $\begin{array}{l}\text { Number of } \\
\text { cases }\end{array}$ & $\begin{array}{c}\% \text { to all } \\
\text { subclinically } \\
\text { mastitis cases }\end{array}$ & \\
\hline $\begin{array}{c}\text { Staphylococcus } \\
\text { aureus }\end{array}$ & 14 & 35.00 & 51 & 50.00 & 45.77 \\
\hline $\begin{array}{l}\text { Streptococcus } \\
\text { agalactiae }\end{array}$ & 12 & 30.00 & 18 & 17.64 & 21.13 \\
\hline E. coli & 5 & 12.50 & 1 & 0.98 & 4.23 \\
\hline Streptococcus species & 3 & 7.5 & 6 & 5.88 & 6.34 \\
\hline Trueperella pyogenes & 1 & 2.5 & $\mathbf{0}$ & $\mathbf{0}$ & 0.70 \\
\hline $\begin{array}{c}\text { Coagulase negative } \\
\text { staphylococci }\end{array}$ & 4 & 10.00 & 20 & 19.61 & 16.90 \\
\hline $\begin{array}{c}\text { Corynebacterium } \\
\text { bovis }\end{array}$ & - & - & 4 & 3.92 & 2.82 \\
\hline Negative culture*** & 1 & 2.5 & 2 & 1.96 & 2.11 \\
\hline
\end{tabular}

Table 3: Antibiotic sensitivity test of some isolated mastitis pathogens.

\begin{tabular}{|c|c|c|c|c|c|c|c|c|c|c|c|c|c|}
\hline \multirow{3}{*}{ 弟 } & \multirow{2}{*}{\multicolumn{7}{|c|}{  }} & \multirow{2}{*}{\multicolumn{2}{|c|}{$\begin{array}{l}\text { Streptococcus } \\
\text { agalactiae }\end{array}$}} & \multicolumn{2}{|c|}{ E. coli } & \multicolumn{2}{|c|}{$\begin{array}{l}\text { Turperrella } \\
\text { pyogenes }\end{array}$} \\
\hline & & & & & & & & & & \multicolumn{2}{|c|}{ Tested isolates } & \multicolumn{2}{|c|}{ Tested isolates } \\
\hline & 1 & 2 & 3 & 4 & 5 & 6 & 7 & 1 & 2 & 1 & 2 & 1 & 2 \\
\hline Pen. & $\mathbf{R}$ & $\mathbf{S}$ & $\mathbf{S}$ & $\mathbf{R}$ & $\mathbf{S}$ & $\mathbf{S}$ & $\mathbf{R}$ & $\mathbf{S}$ & $\mathbf{S}$ & - & - & $\mathbf{S}$ & $\mathbf{S}$ \\
\hline Amox. & $\mathbf{R}$ & $\mathbf{S}$ & $\mathbf{S}$ & $\mathbf{S}$ & $\mathbf{S}$ & $\mathbf{S}$ & $\mathbf{S}$ & $\mathbf{S}$ & $\mathbf{S}$ & - & - & $\mathbf{S}$ & $\mathbf{S}$ \\
\hline Ceph. & $\mathbf{S}$ & $\mathbf{S}$ & $\mathbf{S}$ & $\mathbf{S}$ & $\mathbf{S}$ & $\mathbf{S}$ & $\mathbf{S}$ & $\mathbf{S}$ & $\mathbf{S}$ & $\mathbf{S}$ & $\mathbf{S}$ & $\mathbf{S}$ & $\mathbf{S}$ \\
\hline Cef. & $\mathbf{S}$ & $\mathbf{S}$ & $\mathbf{S}$ & $\mathbf{S}$ & $\mathbf{S}$ & $\mathbf{S}$ & $\mathbf{S}$ & $\mathbf{S}$ & $\mathbf{S}$ & $\mathbf{R}$ & $\mathbf{R}$ & $\mathbf{S}$ & $\mathbf{S}$ \\
\hline Enro. & $\mathbf{S}$ & $\mathbf{S}$ & $\mathbf{S}$ & $\mathbf{S}$ & $\mathbf{S}$ & $\mathbf{S}$ & $\mathbf{S}$ & $\mathbf{S}$ & $\mathbf{S}$ & $\mathbf{S}$ & $\mathbf{S}$ & $\mathbf{S}$ & $\mathbf{S}$ \\
\hline Cipro & $\mathbf{S}$ & $\mathbf{S}$ & $\mathbf{S}$ & $\mathbf{S}$ & $\mathbf{S}$ & $\mathbf{S}$ & $\mathbf{S}$ & $\mathbf{S}$ & $\mathbf{S}$ & $\mathbf{S}$ & $\mathbf{S}$ & $\mathbf{S}$ & $\mathbf{S}$ \\
\hline Oxy. & $\mathbf{S}$ & $\mathbf{R}$ & $\mathbf{S}$ & $\mathbf{S}$ & $\mathbf{S}$ & $\mathbf{S}$ & $\mathbf{R}$ & $\mathbf{S}$ & $\mathbf{S}$ & $\mathbf{S}$ & $\mathbf{S}$ & $\mathbf{S}$ & $\mathbf{S}$ \\
\hline $\begin{array}{l}\text { Pen.:Pen } \\
\text { Cef.:Cefo } \\
\text { Оху.:Ox. }\end{array}$ & $\begin{array}{l}\text { illir } \\
\text { pera } \\
\text { etra }\end{array}$ & $\begin{array}{l}\mathrm{G}( \\
\text { one } \\
\text { ycli }\end{array}$ & $\begin{array}{l}7 \mathrm{IU} \\
75 \mu \\
\text { e }(3\end{array}$ & $\mu g)$ & & & $\begin{array}{l}\text { ox: } \\
\text { o.:E } \\
\text { ens }\end{array}$ & $\begin{array}{l}\text { noxa } \\
\text { oflox } \\
\text { ve }\end{array}$ & $\begin{array}{l}30 \mu \mathrm{g}) \\
0 \mu \mathrm{g}) .\end{array}$ & & $\begin{array}{l}\text { Ceph } \\
\text { Cipr } \\
\text { istan }\end{array}$ & $\begin{array}{l}\operatorname{dine} \\
\text { loxa }\end{array}$ & \\
\hline
\end{tabular}


Table 4: Therapeutic trial and Follow-up of the treated buffaloes with clinical and subclinical Staphylococcus aureus-mastitis.

\begin{tabular}{|c|c|c|c|c|c|c|c|c|c|c|c|}
\hline \multirow[t]{2}{*}{ Day } & \multirow[t]{2}{*}{ Test } & \multicolumn{10}{|c|}{ The treated buffaloes with clinical (c) and subclinical (sc) mastitis (10 cases) } \\
\hline & & 1c & $2 \mathrm{c}$ & $3 c$ & $4 \mathrm{sc}$ & $5 \mathrm{sc}$ & $6 \mathrm{sc}$ & $7 \mathrm{sc}$ & $8 s c$ & $9 \mathrm{sc}$ & 10sc \\
\hline $\begin{array}{c}\text { Before } \\
\text { Therapeutic } \\
\text { trial }\end{array}$ & $\begin{array}{c}C M T \\
\text { Bacteriology } \\
\text { PCR }\end{array}$ & $\begin{array}{c}\text { NP } \\
+ \\
\text { NP }\end{array}$ & $\begin{array}{c}\text { NP } \\
+ \\
\text { NP }\end{array}$ & $\begin{array}{l}\text { NP } \\
+ \\
\text { NP }\end{array}$ & $\begin{array}{c}++ \\
+ \\
\text { NP }\end{array}$ & $\begin{array}{c}++ \\
+ \\
\text { NP }\end{array}$ & $\begin{array}{c}+++ \\
+ \\
\text { NP }\end{array}$ & $\begin{array}{c}+++ \\
+ \\
\text { NP }\end{array}$ & $\begin{array}{c}++ \\
+ \\
\text { NP }\end{array}$ & $\begin{array}{c}+++ \\
+ \\
\text { NP }\end{array}$ & $\begin{array}{c}++ \\
+ \\
\text { NP }\end{array}$ \\
\hline $\begin{array}{c}\text { On the } 5^{\text {th }} \text { day } \\
\text { post the end of } \\
\text { therapeutic } \\
\text { course }\end{array}$ & $\begin{array}{c}C M T \\
\text { Bacteriology } \\
\text { PCR }\end{array}$ & $\begin{array}{c}+++ \\
+ \\
\text { NP }\end{array}$ & $\begin{array}{c}+++ \\
+ \\
\text { NP }\end{array}$ & $\begin{array}{c}++ \\
- \\
+\end{array}$ & $\begin{array}{c}- \\
- \\
\text { NP }\end{array}$ & $\begin{array}{c}- \\
- \\
\text { NP }\end{array}$ & $\begin{array}{c}++ \\
+ \\
\text { NP }\end{array}$ & $\begin{array}{c}++ \\
+ \\
\text { NP }\end{array}$ & $\begin{array}{c}- \\
- \\
\text { NP }\end{array}$ & $\begin{array}{c}+ \\
- \\
+\end{array}$ & $\begin{array}{l}- \\
- \\
-\end{array}$ \\
\hline $\begin{array}{c}\text { On the } 7^{\text {th }} \text { day } \\
\text { post the end of } \\
\text { therapeutic } \\
\text { course }\end{array}$ & $\begin{array}{c}C M T \\
\text { Bacteriology } \\
\text { PCR }\end{array}$ & $\begin{array}{c}+++ \\
+ \\
\text { NP }\end{array}$ & $\begin{array}{c}+++ \\
+ \\
\text { NP }\end{array}$ & $\begin{array}{c}+++ \\
+ \\
\text { NP }\end{array}$ & $\begin{array}{c}- \\
- \\
\text { NP }\end{array}$ & $\begin{array}{c}- \\
- \\
\text { NP }\end{array}$ & $\begin{array}{c}+++ \\
+ \\
\text { NP }\end{array}$ & $\begin{array}{c}+++ \\
+ \\
\text { NP }\end{array}$ & $\begin{array}{c}- \\
- \\
\text { NP }\end{array}$ & $\begin{array}{c}++ \\
+ \\
\text { NP }\end{array}$ & $\begin{array}{c}- \\
- \\
N P\end{array}$ \\
\hline $\begin{array}{l}\text { On the } 10^{\text {th }} \text { day } \\
\text { post the end of } \\
\text { therapeutic } \\
\text { course }\end{array}$ & $\begin{array}{c}C M T \\
\text { Bacteriology } \\
\text { PCR }\end{array}$ & & lled ot & & $\begin{array}{c}- \\
- \\
\text { NP }\end{array}$ & $\begin{array}{c}- \\
- \\
\text { NP }\end{array}$ & $\begin{array}{c}\text { Culled } \\
\text { out }^{*}\end{array}$ & $\begin{array}{c}\text { Culled } \\
\text { out }^{*}\end{array}$ & $\begin{array}{c}- \\
- \\
\text { NP }\end{array}$ & $\begin{array}{c}\text { Culled } \\
\text { out } *\end{array}$ & $\begin{array}{c}- \\
- \\
N P\end{array}$ \\
\hline $\begin{array}{l}\text { On the } 15^{\text {th }} \text { day } \\
\text { post the end of } \\
\text { therapeutic } \\
\text { course }\end{array}$ & $\begin{array}{c}C M T \\
\text { Bacteriology } \\
\text { PCR }\end{array}$ & & & & $\begin{array}{c}- \\
- \\
\text { NP }\end{array}$ & $\begin{array}{c}- \\
- \\
\text { NP }\end{array}$ & & & $\begin{array}{c}- \\
- \\
\text { NP }\end{array}$ & & $\begin{array}{c}- \\
- \\
\text { NP }\end{array}$ \\
\hline $\begin{array}{l}\text { On the } 21^{\text {th }} \text { day } \\
\left(3^{\text {rd }} \text { week }\right) \\
\text { post the end of } \\
\text { therapeutic } \\
\text { course }\end{array}$ & $\begin{array}{c}C M T \\
\text { Bacteriology } \\
\text { PCR }\end{array}$ & & & & $\begin{array}{c}- \\
- \\
\text { NP }\end{array}$ & $\begin{array}{c}- \\
- \\
\text { NP }\end{array}$ & & & $\begin{array}{c}- \\
- \\
\text { NP }\end{array}$ & & $\begin{array}{c}- \\
- \\
\text { NP }\end{array}$ \\
\hline $\begin{array}{l}\text { On the } 4^{\text {th }} \text { week } \\
\text { post the end of } \\
\text { therapeutic } \\
\text { course }\end{array}$ & $\begin{array}{c}C M T \\
\text { Bacteriology } \\
\text { PCR }\end{array}$ & & & & $\begin{array}{c}- \\
- \\
\text { NP }\end{array}$ & $\begin{array}{c}- \\
- \\
\text { NP }\end{array}$ & & & $\begin{array}{c}- \\
- \\
\text { NP }\end{array}$ & & $\begin{array}{c}- \\
- \\
\text { NP }\end{array}$ \\
\hline $\begin{array}{l}\text { On the } \sigma^{\text {th }} \text { week } \\
\text { post the end of } \\
\text { therapeutic } \\
\text { course }\end{array}$ & $\begin{array}{c}\text { CMT } \\
\text { Bacteriology } \\
\text { PCR }\end{array}$ & & & & $\begin{array}{c}- \\
- \\
\text { NP }\end{array}$ & $\begin{array}{c}- \\
- \\
\text { NP }\end{array}$ & & & $\begin{array}{c}- \\
- \\
\text { NP }\end{array}$ & & $\begin{array}{c}- \\
- \\
\text { NP }\end{array}$ \\
\hline $\begin{array}{c}\text { On the } 7^{\text {th }} \text { week } \\
\text { post the end of } \\
\text { therapeutic } \\
\text { course }\end{array}$ & & & & & & $N P$ & & & & & \\
\hline $\begin{array}{l}\text { On the } 8^{\text {th }} \text { week } \\
\text { post the end of } \\
\text { therapeutic } \\
\text { course }\end{array}$ & $\begin{array}{c}C M T \\
\text { Bacteriology } \\
\text { PCR }\end{array}$ & & & & $\begin{array}{c}- \\
- \\
\text { NP }\end{array}$ & $\begin{array}{c}- \\
- \\
\text { NP }\end{array}$ & & & $\begin{array}{c}- \\
- \\
\text { NP }\end{array}$ & & $\begin{array}{c}- \\
- \\
\text { NP }\end{array}$ \\
\hline $\begin{array}{l}\text { On the } 9^{\text {th }} \text { week } \\
\text { post the end of } \\
\text { therapeutic } \\
\text { course }\end{array}$ & $\begin{array}{c}\text { CMT } \\
\text { Bacteriology } \\
\text { PCR }\end{array}$ & & & & $\begin{array}{c}- \\
- \\
\text { NP }\end{array}$ & $\begin{array}{c}- \\
- \\
\text { NP }\end{array}$ & & & $\begin{array}{c}- \\
- \\
\text { NP }\end{array}$ & & $\begin{array}{c}- \\
- \\
\text { NP }\end{array}$ \\
\hline $\begin{array}{c}\text { On the } \\
10^{\text {th }} \text { week } \\
\text { post the end of } \\
\text { therapeutic } \\
\text { course }\end{array}$ & $\begin{array}{c}C M T \\
\text { Bacteriology } \\
\text { PCR }\end{array}$ & & & & $\begin{array}{c}- \\
- \\
-v e\end{array}$ & $\begin{array}{c}- \\
- \\
-v e\end{array}$ & & & $\begin{array}{c}- \\
- \\
-v e\end{array}$ & & $\begin{array}{c}- \\
- \\
-v e\end{array}$ \\
\hline
\end{tabular}






Fig. 1: Regression line and correlation coefficient of lactation seasons of the examined buffaloes upon the infection rate $(\%)$ with clinical mastitis at different lactation seasons $(r=57 \%)$

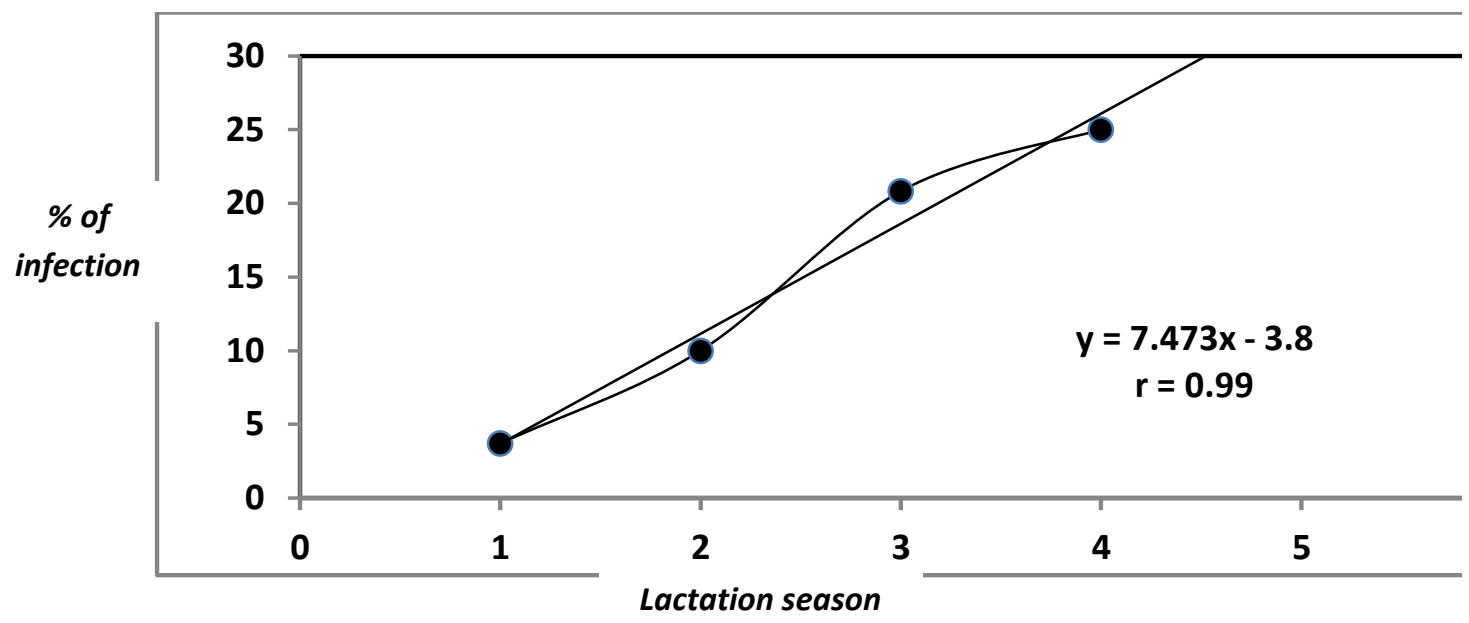

Fig. 2: Linear regression of lactation seasons (set 1 , from the $1^{\text {st }}$ to the $5^{\text {th }}$ season) of the examined buffaloes upon the infection rate $(\%)$ with clinical mastitis $(\mathrm{r}=99 \%)$



Fig. 3: Linear regression of lactation seasons (set 2 , from the $5^{\text {th }}$ to the $>9^{\text {th }}$ season) of the examined buffaloes upon the infection rate $(\%)$ with clinical mastitis $(\mathrm{r}=96 \%)$ 


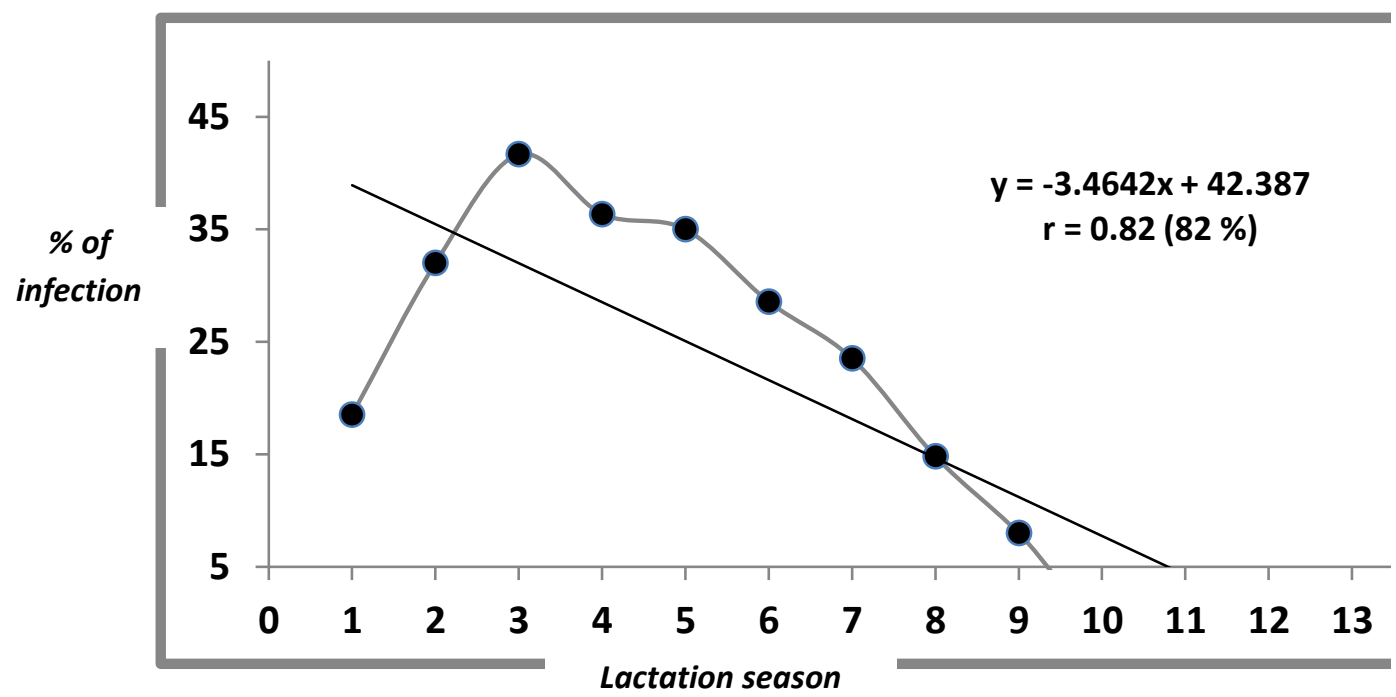

Fig. 4: Regression Line and correlation coefficient of lactation seasons of the examined buffaloes upon the infection rate $(\%)$ with subclinical mastitis at different lactation seasons $(\mathrm{r}=82 \%)$



Fig. 5: Linear regression of lactation seasons (set 1 , from the $1^{\text {st }}$ to the $5^{\text {th }}$ season) of the examined buffaloes upon the infection rate $(\%)$ with subclinical mastitis $(r=97 \%)$

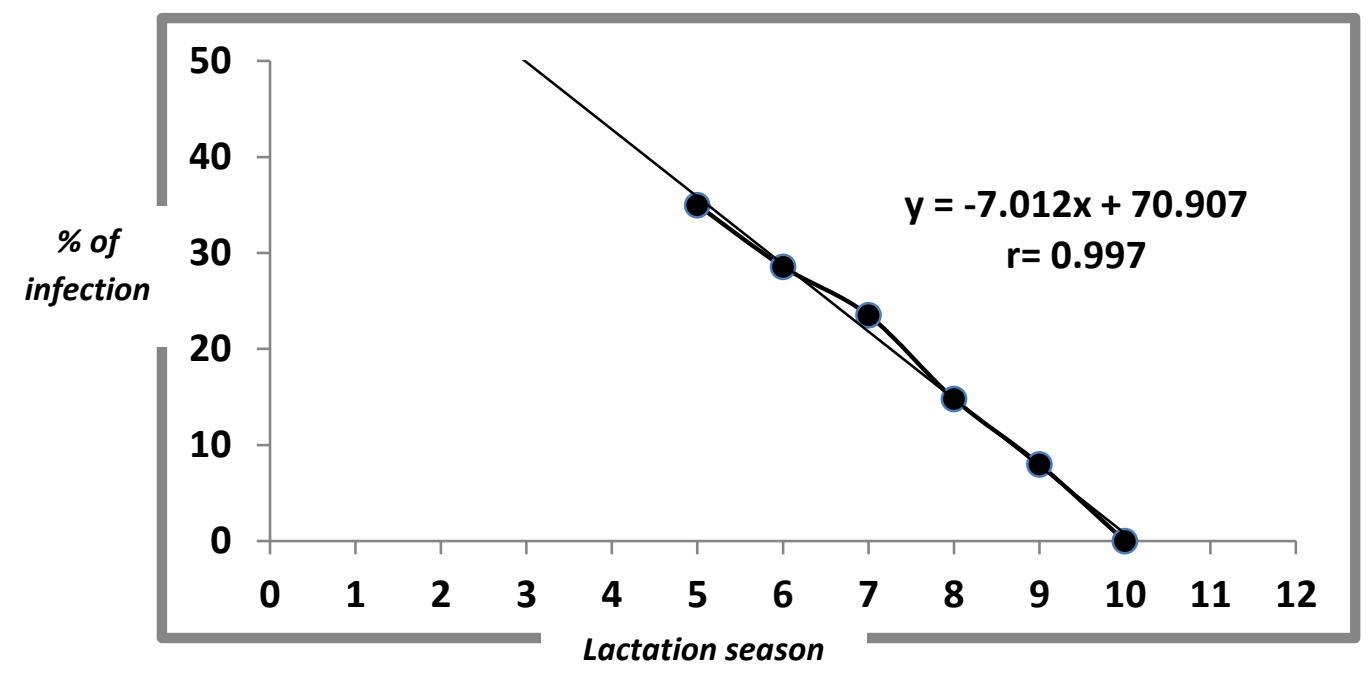

Fig. 6: Linear regression of lactation seasons (set 2 , from the $5^{\text {th }}$ to the $>9^{\text {th }}$ season) of the examined buffaloes upon the infection rate $(\%)$ with subclinical mastitis $(r=99 \%)$. 


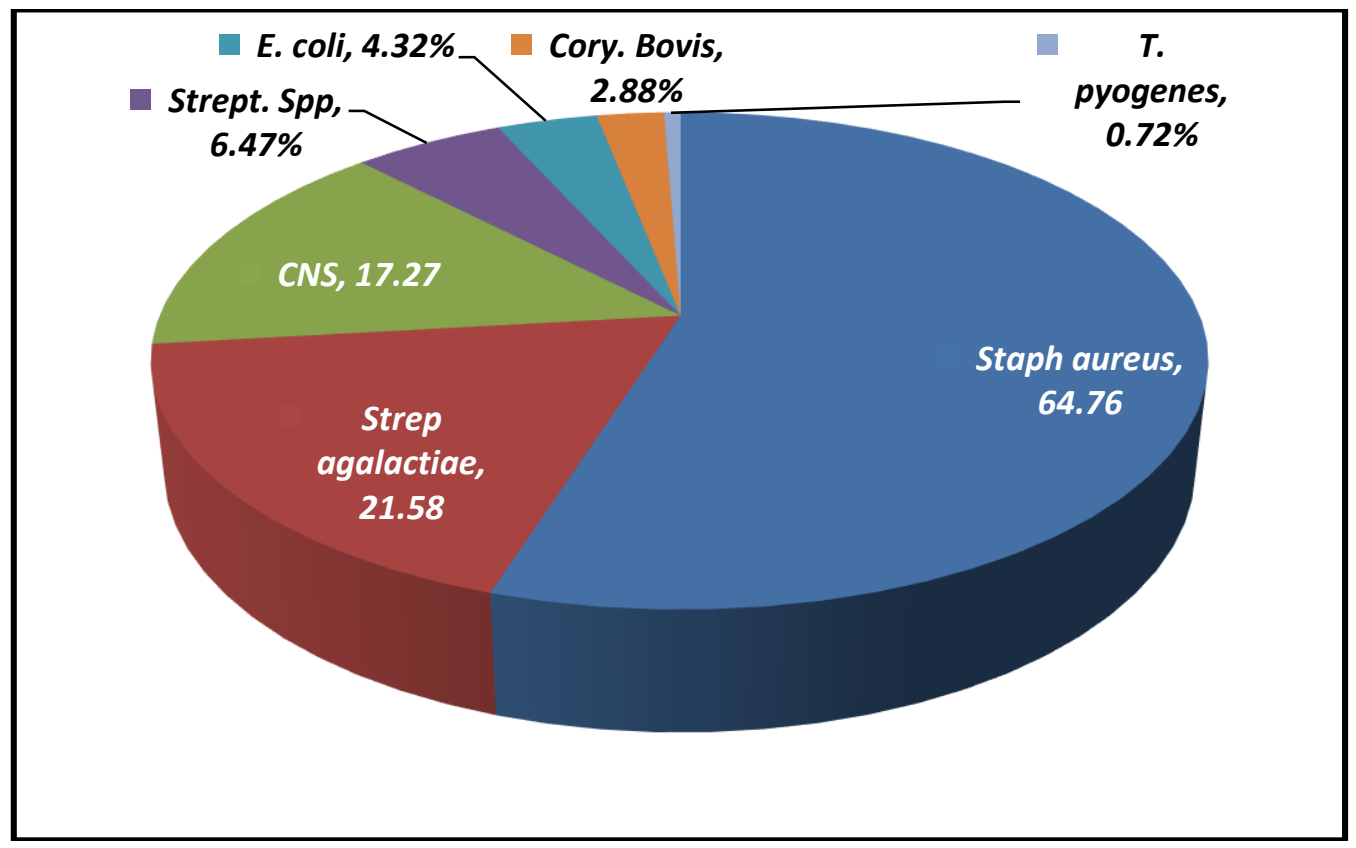

Fig. 7: Frequent $(\%)$ isolation of the major isolated pathogens ( $\mathrm{n}=139$ isolates) from the examined buffaloes with clinical and subclinical mastitis.

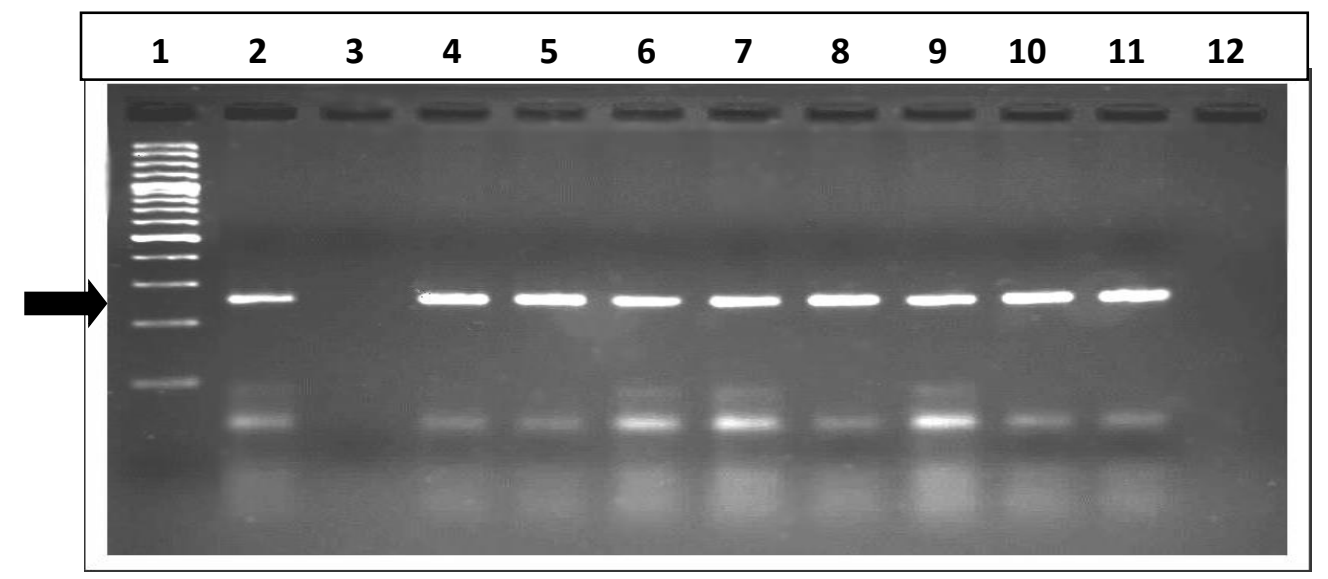

Fig. 8 : Agarose gel electrophoresis of PCR amplification products.

Lane 1: 100 bp ladder as molecular size DNA marker.

Lane 2: Control positive for S. aureus nuc gene. (270 pb, Black arrow)

Lane 3: Control negative for $S$. aureus nuc gene.

Lanes 4-11: Positive samples

Lane 12: Negative sample

\section{DISCUSSION}

Mastitis is a frustrating, costly and extremely complex disease that results in a marked reduction in the quality and quantity of milk (Harmon, 1994). Its vital importance in its association with many zoonotic diseases in which milk acts as a vehicle of pathogens causing tuberculosis and brucellosis (Shoshani et al., 2000).

Currently, the prevalence of the subclinical mastitis is more than prevalence of the clinical mastitis in the examined buffaloes in Sohag Governorate with percentages of $26.84 \%$ and $11.05 \%$ respectively. The result related to Biffa et al. (2005), Abd-ElRazik et al. (2010) and Abd-Elrahman (2013) who found that incidence of subclinical mastitis more prevalent than clinical mastitis in housed buffaloes in El-Bahiera Governorate, Egypt in percentages $18.5 \%$ and $9 \%$ respectively. This difference between the rates of prevalence of mastitis from area to area and from farm to another is result from different hygienic measures, milking sanitation and healthy 
environment applied around dairy animals. (Zaitoun, 1992).

Epizootiologically, the present study indicated that prevalence of clinical and subclinical mastitis increased with increase of lactation number till the fourth lactation season. Thereafter, the rate of infection with mastitis among the investigated buffaloes decreased gradually till reach the $9^{\text {th }}$ lactation season. More than 9 lactations, there is no clinical or subclinical mastitis was noticed. This may refers to a build-up of acquired immunity of the mammary gland of dairy animal. Similar results obtained were previously reported by Zaitoun (2008) and Amer (2010) in Assiut Governorate, Upper Egypt. Zaitoun (2008) carried out a wide survey on $S$. aureus-mastitis in lactating and dried buffaloes of different ages located in Assiut Governorate and concluded that there were negative correlation between prevalence of clinical mastitis and number of lactations of River-Nile buffaloes. The high infection rate during the first three of lactation seasons may associated with the high yield of milk production that increases the stresses factors facilitating intramammary infection. Incidence of infected quarters increases with the age was also reported by (Kumar and Sharma, 2002; Sharma and Prasad, 2002; Sharma et al., 2007; Sharma and Maiti, 2010). On the same manner, EL-Byomi and Mahmoud (1987), Ibrahim (1990) and Osman (1996) reported that the prevalence of subclinical mastitis increased with increasing the age of animal. This result depends on physiological changes occurred in the udder in the advanced age, where the teat of the aged buffalo is more pendulous than in young animals so the risk of exposure to abrasions and wounds is increased which is leading to increase of infection rate.

Concerning the bacteriological examination of the collected milk samples, it was found that coagulase positive S. aureus $(45.77 \%)$ was the predominant isolated pathogen either alone or synchronized with other microorganisms, followed by $S$. agalactiae $(21.13 \%)$ and E. coli $(4.22 \%)$. Such results confirmed results previously published by Poutrel (1983) who concluded that Staphylococci and Streptococci causes $90 \%$ of bovine mastitis. Conversely, the offered results by El-Khodery and Osman (2008) in Kafr El-Sheikh Governorate, Egypt, elucidated that coliform was detected $(80.35 \%)$ in the bacteriologically examined buffaloes and they could isolate Klebsiella pneumoniae $(35.5 \%)$, E. coli $(24.4 \%)$ and mixed infections with both of them (40\%). They also indicated that the isolation rate of $S$. aureus from buffaloes with mastitis reached up-to $12.5 \%$ followed by Streptococcus uberis (5.4\%), and Streptococcus agalactiae (1.8\%). The authors also added that the examined buffaloes were bred in localized farms with bad sanitary measures particularly drainage of waste products and manures. Their results may suggest that environmental mastitis in buffaloes that kept in farms is more prevalent than contagious mastitis. However, ElBalkemy et al. (1997) corroborated that $S$. aureus was one of the most prevalent bacteria in subclinical mastitis of milk-producing animals with manual milking and this may return to milker's hands which consider the main tool in distribution of microorganisms from teat to teat and from animal to another, in addition to lack of hygiene measures. In villages, farmers yield their buffaloes manually due to the low income.

Moreover, the obtained bacteriological results also indicated that the less frequently isolated Trueperella pyogenes from the diseased buffaloes with mastitis may reflects the suppurating nature of infection and explains the yellowish coloration of some milk secreted milk of the examined diseased buffaloes with mastitis. Trueperella pyogenes is pusproducing pathogen causing suppurative mastitis of dairy cows and buffaloes during the lactation and dry seasons particularly at the warm months (Andrews et al., 1992; Zaitoun 2008, Jingar et al., 2014 and Ishiyama et al., 2017).

Regarding the sensitivity test of the main mastitis pathogens isolated from clinical and/or subclinical mastitis cases revealed that Staphylococcus aureus were sensitive to Amoxicillin. Enrofloxacillin and ciprofloxacillin (fluoroquinolones) had strong inhibitory effects on tested strains. Fifty percent of tested strains of $S A$ were penicillin resistant. The same result obtained with oxytetracycline. The tested strains of $S$. aureus, Streptococcus agalactiae and Arcanobacterium pyogenes were sensitive to amoxicillin, cephoperazone but E.coli were resistant. Similar antibiogram pattern was reported by Akram et al. (2013) which revealed that Penicillin was found to be least effective antibiotic against bacterial isolates but enrofloxacin, norfloxacin and gentamycin proved to be the most effective antimicrobials against mastitis causing bacteria. And Mustafa et al. (2011) said that the disease was found to be highly sensitive to ciprofloxacin. Conversely, Hameed et al. (2008) found that amoxicillin was the least effective.

On the current work, the identification of S.aureus isolates was performed conventionally and with PCR method. Brakstad et al. (1992) have developed a PCR assay specific for $S$. aureus by targeting the nuc gene coding for staphylococcal thermonuclease. This assay was to be suitable for diagnostic purposes (Abd-El-Razik et al., 2010) and this method was used in this study for identification S. aureus isolates which gave nuc gene; amplicon 270-bp that was 
amplified from the genomic DNA of $\mathrm{S}$. aureus (figure 2). Eight S.aureus isolates (Lanes 4-11) gave positive results. The obtained results agreed with the result reported by (Ali and Mahmoud, 2016) who used the same method for identification S. aureus isolates which gave nuc gene; amplicon 276-bp. 21 $\mathrm{S}$. aureus isolates were positive by PCR.

In conclusion, Staphylococcus aureus is an outstanding mastitogen of buffaloes and early detection considers a crucial goal in control. The infection rate with mastitis was peak at the $3^{\text {th }}$ and $4^{\text {th }}$ lactation seasons. Therapeutic trial concluded that Staphylococcus aureus is notorious pathogen and shedding pattern of that pathogen is intermittent. PCR is a valuable fast test for detection of mastitogens than culture techniques but it is still precious practically.

\section{REFERENCES}

Abd-Elrahman, A.H. (2013): Mastitis in housed dairy buffaloes: incidence, etiology, clinical finding, antimicrobial sensitivity and different medical treatment against E. coli mastitis. Life Sci. J., 10 (1): 532-538.

Abd El-Razik, K.A.; Khaled, A. Abdelrahmanb; Youssef F. Ahmed; Alaa M. Gomaa and Hazem A. Eldebaky (2010): Direct Identification of Major Pathogens of the Bubaline Subclinical Mastitis in Egypt using PCR. Journal of American Science, 6(10): 652-660.

Akram, N.; Chaudhary, A.H.; Ahmed, S.; Ghuman, M.A.; Nawaz, G. and Hussain, S. (2013): Isolation of bacteria from mastitis affected bovine milk and their antibiogram. European Journal of Veterinary Medicine, 2: 38-46.

Ali, A.O. and Mahmoud, H.Y. (2016): Sequencing and Phylogenetic Characterization of $S$. aureus Thermonuclease Gene. Assiut Vet. Med. J. 62(148):6-12.

Amer, M. (2010): Study on Mastitis of Dairy Buffaloes. M.V.Sc. Thesis, Faculty of Veterinary Medicine, Assiut University, Egypt.

Anand Kumar, P. (2009): Evaluation of PCR test for detecting major pathogens of bubaline mastitis directly from mastitic milk samples of buffaloes. Trop Anim Health Prod 41: 1643-1651.

Andrews, A.H.; Blowey, R.W.; Boyd, W. and Eddy, R.G. (1992): Bovine Medicine diseases and Husbandry of cattle. Blackwell Scientific Publications.

Bauer, A.W.; Kirby, W.M.; Sherris, J.C. and Turck, M. (1966): Antibiotic susceptibility testing by a standardized single disk method. Amer. J. Clin. Path. 45(4). 493-496.
Bhatti, JA.; Younas, M.; Abdullah, M.; Babar, ME. and Nawaz, H. (2009): Feed intake, weight gain and haematology in Nili-Ravi buffalo heifers fed on mott grass and Berseem fodder substituted with saltbush (Atriplex amnicola). Pakistan Vet. J., 29(3): 133-137.

Biffa, D.; Debela, E. and Beyene, $F$. (2005): Prevalence and risk factors of mastitis in lactating dairy cows in Southern Ethiopia. Int. J. App. Res. Vet. Med., 3: 189198.

Brakstad, O.G.; Aasbakk, K. and Maelamd, J.A. (1992): Detection of Staphylococcus aureus by polymerase chain reaction amplification of nuc gene. Journal of Clinical Microbiology 30, 1654-1660.

Cai, H.Y.; Archambault, M.; Gyles, CL. and Prescott, JF. (2003): Molecular genetics methods in the veterinary clinical bacteriology laboratory: current usage and future applications. Animal Health Research Reviews 4: 73-93.

Chatfield (1970): Regression and correlation. In Statistics for Technology. The $1^{\text {st }}$ Ed. Penguin Books Baltimore, Maryland. Pp. 166-199.

CLSI (2008): Performance standards for antimicrobial susceptibility testing. $18^{\text {th }}$ informational supplement CLSI document M100-s18Clin. and Labor. Stand. Insti. Wayne, PA.

CLSI (2014): Performance standards for antimicrobial susceptibility testing. $25^{\text {th }}$ informational supplement CLSI document M100-s125Clin. and Labor. Stand. Insti. Wayne, PA.

Daly, P.; Collier, T. and Doyle, S. (2002): PCRELISA detection of Escherichia coli in milk. Letters in Applied Microbiology 34: 222-226.

El-Khodery, S.A. and Osman, S.A. (2008): Acute coliform mastitis in buffaloes (Bubalus bubalis): clinical findings and treatment outcomes. Tropical animal health and production, 40(2), 93-99.

El-Balkemy, F.A.; Esmat, M.; Menazie, Afaf and Farag, Azza N. (1997): Evaluation of screening tests used for detection of subclinical mastitis. 4th Sci. Cong. Egyptian Society for Cattle Diseases, Assiut, Egypt. pp 181.

El-Byomi, Kh.M. and Mahmoud, A.A. (1987): Some genetic and environmental factors affecting the incidence of subclinical mastitis in dairy animals. Journal of Veterinary Medicine, 35, 3, 269-385.

Gudding, R.; McDonald, J.S. and Cheville, N.F. (1984): Pathogenesis of Staphylococcus aureus mastitis: Bacteriologic, histologic, and ultra structure pathogenic finding. Am. J. Vet. Res. 45: 2525-2531. 
Hameed, S.; Arshad, M.; Ashraf, M.; Avais, M. and Shahid, M.A. (2008): Prevalence of common mastitogens and their antibiotic susceptibility in Tehsil BUREWALA, PAKISTAN. Pak. J. Agri. Sci., Vol. 45(2).

Hatakka, M.; Bjorkroth, K.; Asplud, K.; Petays, N.; Korkeala, H. (2000): Genotypes and enterotoxicity of Staphylococcus aureus isolated from the hands and nasal cavities of flight-catering employees. J. Food Protect., 63:1487-1491.

Haynes, N.B. (1985): Diseases caused by bacterial mastitis in keeping life stock healthy. Ed. by Haynes, story communication inc. Pawnal Vermont 052.

Harmon, R.J. (1994): Physiology of mastitis and factors affecting somatic cell counts. J. Dairy Sci. 77: 2103.

Ibrahim, K.M.S. (1990): Some studies on mastitis in cattle. M V. Sc. Thesis, Faculty of veterinary Medicine, Suez Canal University, Egypt.

Ishiyama, D.; Tomoko Mizomoto; Chise Ueda; Nobuyuki Takagi.; Noriko Shimizu; Yu Matsuura; Yuto Makuuchi; Aiko Watanabe; Yasunori Shinozuka and Kazuhiro Kawai (2017): Factors affecting the incidence and outcome of Trueperella pyogenes mastitis in cows J. Vet. Med. Sci., 23. 79. 3: 626-631

Jackson, P.G.G. and Cockroft, P.D. (2002): Clinical examination the of the udder. In clinical examination of farm animals. Blackwell Science Ltd, $1^{\text {st }}$ Edition, Chapter (12): 154166.

Javaid, SB, Gadahi, JA.; Khaskeli, M. Bhutto, MB.; Kumbher, S. and Panhwar, AH. (2009): Physical and chemical quality of market milk sold at Tandojam, Pakistan. Pakistan Vet. J, 29(1): 27-31.

Jayarao, BM.; Dore, JJ.; Baumbach, GA.; Matthews, KR. and Oliver, SP. (1991): Differentiation of Streptococcus uberis from Streptococcus parauberis by polymerase chain reaction and restriction fragment length polymorphism analysis of $16 \mathrm{~S}$ ribosomal DNA. J. Clin. Microbiol. 29:2774-2778.

Jingar, S.C.1.; Mehla, R.K.1. and Singh, M. (2014): Climatic effects on occurrence of clinical mastitis in different breeds of cows and buffaloes. Arch. Zootec. 63 (243): 473-482.

Jones, G.M.; Bailey, T.L. and Roberson, J.R. (1998): Staphylococcus aureus mastitis: Cause, Detection, and Control. Virginia-Maryland Regional College of Veterinary Medicine, Virginia Tech Publication Number 404-229.

Kelly, W.R. (1984): Veterinary Clinical Diagnosis. $3^{\text {rd }}$ ed. Bailliere Tindall. London.

Koneman, E.W.; Allen, S.D.; Dowell, V.R.; Janda, W.H. and Sommers, H.M. (1992): Color atlas and Textbook of Diagnostic Microbiology. 4TH Ed., J.B. Lippincott CO., New York.
Kozytska, S.; Staul, D.; Pawlik, MC.; Hensen, S.; Eckart, M.; Ziebuhr, W.; Witte, W. and Ohlsen, K. (2010): Identification of specific genes in Staphylococcus aureus strains associated with bovine mastitis. Veterinary Microbiology (under publication).

Kumar, R. and Sharma, A. (2002): Prevalence, etiology and antibiogram of mastitis in cows and buffaloes in Hisar, Haryana. Ind. J. Anim. Sci., 72: 361-363.

McDowell, RE.; Wilk, JC.; Shah, SK.; Balain, DS. and Metyry, GH. (1995): Potential for Commercial Dairying with Buffalo. North Carolina State University, USA.

Meddis, $R$ (1975): Statistical Handbook for NonStatisticians. The $1^{\text {st }}$ Ed. McGraw Hill Book Company (UK) Limit.

Meiri-Bendek, I.; Lipkin, E.; Friedmann, A.; Leitner, G.; Saran, A.; Friedman, S. and Kashi, Y. (2002): A PCR-based method for the detection of Streptococcus agalactiae in milk. J. Dairy Sci. 85: 1717-1723.

Miller, R.H.; Pape, M.J.; Fulton, L.A. and Schutz, M.M. (1993): The relationship of milk and somatic cell count to milk yields for Holstein heifers after first calving. J. Dairy Sci. 76:728.

Mustafa, Y.S.; Awan, F.N.; Zaman, T.; Chaudhry, S.R. and Zoyfro, V. (2011): Prevalence and antibacterial susceptibility in mastitis in buffalo and cow in and around the district LAHORE-PAKISTAN. Pak. J. Pharm. 24 (1 \& 2) 29-33.

National committee for Clinical Laboratory Standards (1984): Performance standards for antimicrobic disc susceptibility tests. $3^{\text {rd }} \mathrm{Ed}$. Approved standards M2-A3. National committee for Clinical laboratory Standards, Villanova, Pa, USA.

Osman, S.A. (1996): Some studies on mastitis in cattle. M.V. Sc. Thesis, Faculty of veterinary Medicine, Tanta University, Egypt. Pages: 127.

Phuektes, P.; Mansell, PD. and Browning, GF. (2001): Multiplex Polymerase Chain Reaction Assay for Simultaneous Detection of Staphylococcus aureus and Streptococcal Causes of Bovine Mastitis. J. Dairy Sci. 84:1140-1148.

Poutrel, B. (1983): Comparative evaluation of commercial latex agglutination and coagulation reagents for group B, C and D mastitis streptococci. Amer. J. Vet. Res. 44:490.

Quinn, P.J.; Carter, M.E.; Markey, B.K. and Carter, G.R. (1994): Clinical Veterinary Microbiology. Mosby. Yearbook Europe Limited. 
Ranjan, R.; Gupta, M.K.; Singh, S. and Kumar, S. (2010): Current trend of drug sensitivity in bovine mastitis. Vet. Journal 3(1): 17-20.

Saleh, IA. (2005): Studies on milk production of buffaloes. Ph. D. thesis, Fac. of Agric. Mansoura Univ. Egypt.

Sharif, A. and Muhammad, G. (2009): Mastitis control in dairy animals. Pakistan Vet. J, 29 (3): 145-148.

Sharma, A.K. and Prasad, B. (2002): Microbial profile and antibiogram studies in mastitic dairy animals of Palampur of H.P. Proceedings of the 10th Indian Society of Veterinary Medicine, February 14-18, 2002, Bikaner, Rajasthan, India, pp: 93-93.

Sharma, H.; Maiti, S.K. and Sharma, K.K. (2007): Prevalence, etiology and antibiogram of microorganisms associated with sub-clinical mastitis in buffaloes in durg, Chhattisgarh state (India). Int. J. Dairy Sci., 2: $145-151$.

Sharma, N. and Maiti, S.K. (2010): Incidence, etiology and antibiogram of sub clinical mastitis in cows in durg, Chhattisgarh. Indian J. Vet. Res., 19: 45-54.

Shoshani, E.; Leitner, G.; Hanochi, B.; Saran, A.; Shpigel, N. and Berman, A. (2000): Mammary infection with Staphylococcus aureus in cows: progress from inoculation to chronic infection and its detection. J. Dairy Res. 67:155.

Sindhu, N.; Sharma, A. and Jain, VK. (2010): Coagulase gene based molecular detection of Staphylococcus aureus directly from mastitic milk samples of Murrah buffalo. Buffalo Bull; 29 (1): 52-59.

Watts, J.L. (1990): Bovine Mastitis. Cited by Carter, G.R. and Cole, J.R. Jr. (1990): In Diagnostic Procedures in Vet. Bacteriology and Mycology. $4^{\text {th }}$ Edition, Academic Press Inc.

Zaitoun, A.M.A (1992): Klebsiella pnemoniae mastitis in dairy cows. Assiut Veterinary Medical Journal, 27, 54, 179-188.

Zaitoun, A.M.A. (2008): Clinical mastitis caused by Staphylococcus aureus in dairy buffaloes. Assiut Vet. Med. J., 54, 119, 289-310.

\section{الكثف التقليدي والجزيئي عن المكور العنقودي الذهبي داخل الضرع في حالات إلتهاب الضرع السريري والإكلينيكي

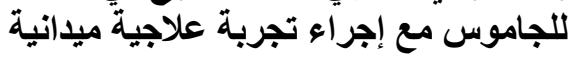

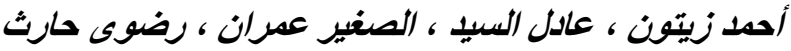

Email: amazaitoun@aun.edu.eg. Assiut University web-site: www.aun.edu.eg

كان الهدف من العمل المقدم قياس معدل إنتشار عدوى الميكروب العنقودي الذهبي المسبب لالتهاب الضر ع الخفي أو الظـاهري في

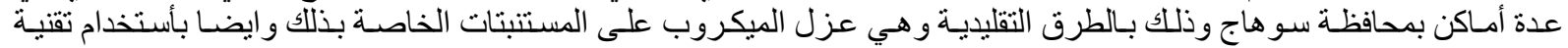

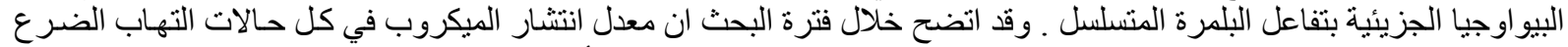

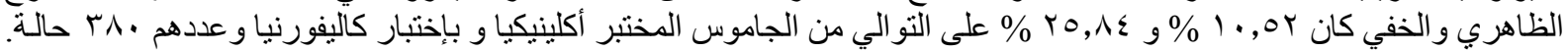

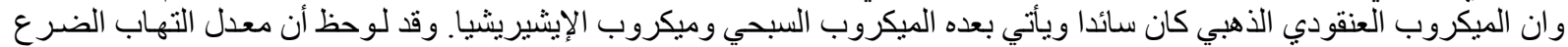

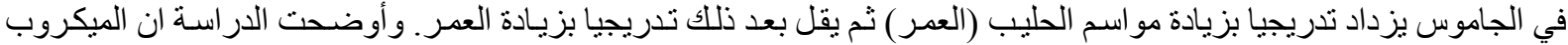

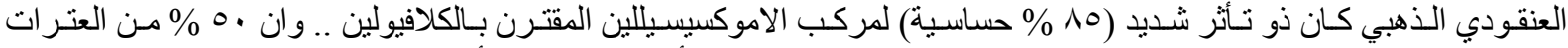

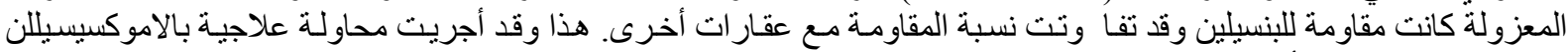

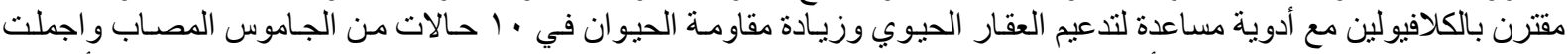



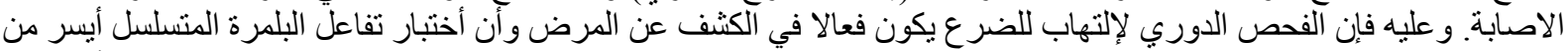

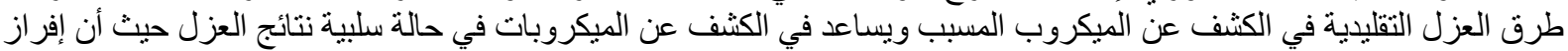

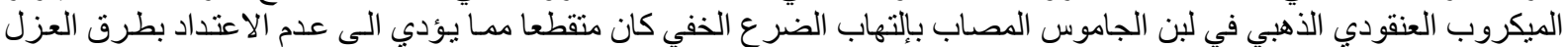

